\title{
Effects of nitrogen and phosphorus fertilizer levels on growth and development of barley (Hordeum vulgare L.) at Bore District, Southern Oromia, Ethiopia
}

\author{
Wakene Tigre $^{1, \text { *, Walelign Worku }}{ }^{2}$, Wassie Haile ${ }^{3}$ \\ ${ }^{1}$ Yabello Pastoral and Dryland Agriculture Research Center, yabello, Ethiopia \\ ${ }^{2}$ Departement of Plant Science, Hawassa University, Hawassa, Ethiopia \\ ${ }^{3}$ Departement of Soil Science, Hawassa University, Hawassa, Ethiopia
}

Email address:

wakene_1983@yahoo.com (W. Tigre),walelignworku@yahoo.uk.co (W. Worku),wassiehaile@yahoo.uk.co (W. Haile)

\section{To cite this article:}

Wakene Tigre, Walelign Worku, Wassie Haile. Effects of Nitrogen and Phosphorus Fertilizer Levels on Growth and Development of Barley (Hordeum vulgare L.) at Bore District, Southern Oromia, Ethiopia. American Journal of Life Sciences. Vol. 2, No. 5, 2014 , pp. $260-266$.

doi: 10.11648/j.ajls.20140205.12

\begin{abstract}
Fertilizer requirement of crops vary from location to location owing to several factors. Thus there is a need to determine site specific fertilizer recommendation for specific crops. Accordingly, an experiment was conducted on the effects of different nitrogen and phosphorus fertilizer levels on yield and yield components of barley at south eastern Oromia, Bore, in 2009 cropping season. The barley variety Biftu was used as test crop. It is a newly released variety from Sinana Agricultural Research Center. The experiment contained factorial combination of five levels of $\mathrm{N}\left(0,30,60,90\right.$ and $\left.120 \mathrm{Kg} \mathrm{ha}^{-1}\right)$ and four levels of $\mathrm{P}\left(0,23,46\right.$ and $\left.69 \mathrm{Kg} \mathrm{ha}^{-1}\right)$ laid out in randomized complete block design with four replications. Application of $\mathrm{N}$ significantly prolonged number of days to heading and maturity and grain filling period. Number of fertile tillers, total biomass and straw yield were significantly increased by application of $\mathrm{N}$. However, the effect of $\mathrm{N}$ on plant height and number of total tillers was not significant. On the other hand, $\mathrm{P}$ application significantly influenced all the parameters of growth and development. Contrary to N, increase in P significantly shortened number of days to heading and maturity and grain filling period. Number of fertile tillers was significantly increased by $\mathrm{P}$ application. The interaction effect of $\mathrm{N}$ and $\mathrm{P}$ was significant on days to heading and number of fertile tillers. Therefore, balanced amount of $\mathrm{N}$ and $\mathrm{P}$ is very essential for appropriate growth of barley.
\end{abstract}

Keywords: Barley, Nitrogen, Phosphorus, Fertilization, Phenology, Growth, Development

\section{Introduction}

Barely (Hordeum Vulgare L.) is one of the most important food crops produced in the world. It assumes the fourth position in total cereal production in the world after wheat, rice and maize. Many countries grow barley as a commercial crop. Russia, Canada, Germany, Ukraine and France are the major barley producers, accounting for nearly half of the total world production (Edney and Tipples, 1997).

It is also one of the most important staple food crops produced in the highland areas of Ethiopia. Its grain is used for the preparation of different foodstuffs, such as injera, kolo, and local drinks, such as tela, borde and beer. The straw is used as animal feed, especially during the dry season. Ethiopia is also considered to be the origin and center of diversity for barley. Besides its use as food, feed and beverage barely has many important features. It is adapted to wide environmental condition, matures soon and has high yield potential. (Hailu and Van Leur Joop, 1996).

Despite, the importance of barely and its many useful characteristics, there are several factors affecting its production. The most important factors that reduce yield of barley in Ethiopia are poor soil fertility, water logging, drought, frost, soil acidity, diseases and insects, and weed competition (ICARDA, 2008). Poor soil fertility and low $\mathrm{pH}$ are among the most important constraints that threaten barley production in Ethiopia. Since the major barley producing areas of the country are mainly located in the highlands, severe soil erosion and lack of appropriate soil conservation practices in the past have resulted in soils with low fertility and $\mathrm{pH}$ (Grando and McPherson, 2005). Particularly 
deficiency of nitrogen and phosphorus is the main factor that severely reduces the yield of barely. According to Desta Beyene (1987), although soil fertility status is dynamic and variable from locality to locality, and it is difficult to end up with a blanket recommendation invariably, some soil amendment studies were undertaken at different times and places.

Even though several researches have been conducted on high land areas of Ethiopia, like Bale, Arsi, Gojam, and central part of the country, there are as yet much barley producing highland areas starving of new technology, including improved varieties and appropriate rate of fertilizer, among which highland area of Guji Zone is one. In this area barley is a staple food crop for large number of people. In Bore Woreda, from the total 16531.36 ha area of land under cultivation, barley covers 6568.79 ha which accounts $39.74 \%$ of the total. To feed this large number of people and ever increasing population, increasing crop productivity per unit area should be given due emphasis.

According to some informal surveys and information from Bureau of Agriculture and Rural Development, the area was very far from research (Personal communication). There were no research conducted concerning fertilizers and other agronomic researches, breading etc. As a result of this fact, the farmers rely on traditional practices and local cultivars. Most of the farmers in Bore do not use fertilizer and few others use very much below the recommended rate. Therefore, there is a need to study the effect of different NP rates on the yield and yield components of barely to determine biological and economic optimum NP rate for barley production at Bore.

\section{Materials and Methods}

\subsection{Description of Study Area}

This experiment was conducted at Bore Woreda, Guji zone of Oromia regional state, Ethiopia, during the 2009 cropping season. Crop growth duration was from mid-July to midNovember. It is found at longitude of $038^{\circ} 37^{\prime} 54.1^{\prime \prime} \mathrm{E}$ and latitude of $06^{\circ} 1^{\prime} 06.7^{\prime \prime} \mathrm{N}$. The altitude of the woreda ranges from 1450 to 2900 m.a.s.l (meters above sea level) with a rugged topography, and the altitude of the specific site is 2712 m.a.s.1

\subsection{Soil Analysis}

For soil analysis, before planting four soil samples were randomly taken from the experimental site at a depth of 30 $\mathrm{cm}$ using an auger and the samples were mixed thoroughly to produce one representative composite sample of $1 \mathrm{~kg}$. Samples were also taken later at harvest from each plot and composite sample of $1 \mathrm{~kg}$ was produced on treatment basis rather than plot base.

\subsection{Experimental Methods}

The treatment consisted of combination of five levels of $\mathrm{N}$ $\left(0,30,60,90\right.$ and $\left.120 \mathrm{~kg} \mathrm{~N} \cdot \mathrm{ha}^{-1}\right)$ and four levels of $\mathrm{P}(0,23,46$ and $69 \mathrm{~kg} \mathrm{P} \mathrm{ha}{ }^{-1}$ ). The twenty treatment combinations were replicated four times in factorial RCB Design. Nitrogen was applied in the form of urea, while $\mathrm{P}$ was applied in the form of triple supper phosphate (TSP). Nitrogen was applied in split, half during sowing and half at booting stage. There were a total of $20 \times 4=80$ plots, each measuring $3 \mathrm{~m} \mathrm{x} 2.4 \mathrm{~m}$ $\left(7.2 \mathrm{~m}^{2}\right)$. Spacing of $1 \mathrm{~m}$ between blocks and $0.5 \mathrm{~m}$ between plots were used.

\subsection{Data Collection and Analysis}

The data were collected as: days to emergence, days to heading, grain filling period, days to maturity, plant height, lodging, number of total tillers, number of fertile tillers and total biomass.

The data was subjected to Analysis of Variance (ANOVA) using SAS (2004) statistical software version 9.2. Mean separation was done using (LSD) test at 5\% probability level.

Lodging was recorded according to Caldicott and Nuttall (1979) lodging index (LI). The angle of lodging was measured on $1-5$ scale $(0=$ no lodging, $5=$ completely lodged and intermediate reading of lodging were expressed as scores 1-4 according to the angle of lodging). An index feature for each plot from the score and percentage assessments were then calculated as follows:

$$
\mathrm{LI}=\sum \frac{\text { (lodging scores } \mathrm{X} \text { their respectlve area lodged) }}{5}
$$

\section{Results and Discussions}

Table 1. Soil physical and chemical properties of the experimental site before planting

\begin{tabular}{ll}
\hline Properties & Value \\
\hline Soil depth $(\mathrm{cm})$ & $0-30$ \\
Chemical properties & \\
$\mathrm{CEC}\left(\mathrm{c} \mathrm{mol} \mathrm{Kg}^{-1}\right)$ & 29.00 \\
$\mathrm{pH}$ & 6.02 \\
Organic matter $(\%)$ & 4.53 \\
Organic carbon $(\%)$ & 2.60 \\
Total nitrogen $(\%)$ & 0.24 \\
Available phosphorus $\left(\mathrm{mg} \mathrm{Kg}^{-1}\right)$ & 6.60 \\
Physical properties $(\%)$ & \\
Sand & 14.10 \\
Silt & 30.50 \\
Clay & 55.40 \\
Textural class & Clay loam \\
\hline
\end{tabular}

\section{Soil and agro-climatic conditions of the area}

Pre planting soil analysis result indicated that texture of the soil is clay loam. $\mathrm{pH}$ of the soil was 6.02 (slightly acidic) (Table 1.). Plant nutrients are most available at $\mathrm{pH}$ varying from 5.5 to 7 (CLDB, 2001). However, different crops have different requirements. Optimum $\mathrm{pH}$ range for barley is 6.0 to 7.0 (CLDB, 2001). Therefore, the $\mathrm{pH}$ of soil is suitable for barley. Other soil chemical properties were: organic matter (OM) content $4.53 \%$, total N $0.24 \%$, available P 6.6 $\mathrm{mg} \mathrm{Kg}{ }^{-1}$ and CEC $29 \mathrm{cmol} \mathrm{Kg}^{-1}$. According to Westerman (1990) rating, organic matter content of soil is very low 
$(<1 \%)$, low (1.0 to 2.0$)$, medium (2.1 to 4.2$)$, high (4.3 to 6$)$, and very high $(>6)$. Total Nitrogen $(\mathrm{TN} \%)$ is rated by Havlin et al. (1999) as very low $(<0.1)$, low $(0.1$ to 0.15$)$, medium $(0.15$ to 0.25$)$, and high $(>0.25)$. According to Olsen et al. (1954) rating, $\mathrm{P}\left(\mathrm{mg} \mathrm{Kg}^{-1}\right)$ content is: $(<3)$ very low, (4 to 7) low, ( 8 to 11$)$ medium, $(>11)$ high. Then available $P$ at the site was within low range. Generally, the soil of the site has medium TN. It might be because of this that some growth and yield components responded better to $\mathrm{P}$ than to $\mathrm{N}$.

The mean annual rainfall of the area is $1496 \mathrm{~mm}$, and the mean annual temperature of the area ranges from 10.1 to $20^{\circ} \mathrm{C}$.

\subsection{Phonological Parameters}

\subsubsection{Days to Emergence}

Days to emergence generally took 9 to 10 days. Statistically, there was no significant difference for days to emergence for the factors $\mathrm{N}$ and $\mathrm{P}$, and their interaction (Table 3). During germination the seedling mostly depends on stored food than on external nutrient. Because of this, significant variation might not be observed on days to emergence by fertilizer application. This is in conformity with finding of Shrivastava et al. (1992) who reported that plants depends mostly on stored food than on external nutrients for germination.

\subsubsection{Days to Heading}

Table 2. Mean number of days to heading as affected by the interaction effect of $N$ and $P$ rates

\begin{tabular}{|c|c|c|c|c|c|}
\hline \multirow[b]{2}{*}{ N Kg ha ${ }^{-1}$} & \multicolumn{5}{|c|}{ P Kg ha ${ }^{-1}$} \\
\hline & 0 & 23 & 46 & 69 & Mean \\
\hline 0 & 89.00 & 75.25 & 72.75 & 71.50 & 77.13 \\
\hline 30 & 90.25 & 78.75 & 74.00 & 69.50 & 78.13 \\
\hline 60 & 92.25 & 80.00 & 73.50 & 76.25 & 80.50 \\
\hline 90 & 93.25 & 76.00 & 75.75 & 72.50 & 79.38 \\
\hline 120 & 95.25 & 77.00 & 76.00 & 72.50 & 80.19 \\
\hline Mean & 92.00 & 77.40 & 74.40 & 72.45 & \\
\hline LSD & 2.40 & & & & \\
\hline
\end{tabular}

$(\mathrm{P}<0.05)$

Days to heading was significantly affected by $\mathrm{N}, \mathrm{P}$ and their interaction (Table 3). Under no $\mathrm{P}$ application, days to heading showed an increasing tendency with rising $\mathrm{N}$ rates (Table 4.). On the other hand, for $\mathrm{P}$ rates between 23 and 69 $\mathrm{Kg} \mathrm{ha}{ }^{-1}$, the number of days to heading did not show a consistent increasing trend with increasing $\mathrm{N}$. Lack of increasing trend between 23 and $69 \mathrm{Kg} \mathrm{ha}^{-1} \mathrm{P}$ rates could be attributed to the counteracting effects of $\mathrm{P}$ nutrition on $\mathrm{N}$ nutrition because $\mathrm{N}$ tends to increase vegetative growth, while $\mathrm{P}$ hastens it. As a result, the treatments with 120-0 and 90-0 $\mathrm{Kg} \mathrm{ha}^{-1}$ significantly took more number of days to heading, while the treatment with NP combination of 30-69
$\mathrm{Kg} \mathrm{ha}^{-1}$ took the shortest number of days to heading (Table 4.). Rashid et al. (2007) reported that NP application significantly affects days to heading of barley.

\subsubsection{Days to Maturity}

Days to maturity were significantly affected by $\mathrm{N}$ and $\mathrm{P}$ treatments, but their interaction was not significant (Table 3). $\mathrm{N}$ and $\mathrm{P}$ rates oppositely affected days to maturity (Table 4). Delay in maturity time of barley was greater at higher rates of $\mathrm{N}$. The three top $\mathrm{N}$ rates 120,90 and $60 \mathrm{Kg} \mathrm{ha}^{-1}$ were at par among each other and they were significantly different from the other two treatments. About eight more days were required for the $120 \mathrm{Kg} \mathrm{ha}^{-1} \mathrm{~N}$ treatment when compared to the control which took 121 days to maturity (Table 4). This might be attributed to the behavior of the fertilizer $\mathrm{N}$ which increases vegetative growth of crops whereby it delays maturity time. Similar result was reported by Damene Darota (2003) from similar experiment conducted on wheat, indicating that significant differences due to $\mathrm{N}$ treatments were observed in the field with respect to plant maturity. Also, Woinshet Tariku, (2007) reported that $\mathrm{N}$ delays maturity.

Phosphorus affected days to maturity in an opposite manner to N (Table 4). Days to maturity was decreased with increasing rate of $\mathrm{P}$ fertilizer, generally. 143 days were required by the control treatment whereas only 117 days were required by the rate of $69 \mathrm{Kg} \mathrm{P} \mathrm{ha}^{-1}$. The top two levels, 69 and $46 \mathrm{Kg} \mathrm{P} \mathrm{ha}^{-1}$, were at par with each other but they were significantly different from the remaining treatments. This might be attributed to the role of $\mathrm{P}$ in plants, that it is used in dry matter distribution which facilitates plant development. In addition, $\mathrm{P}$ is vital to plant growth and is found in every living plant cell. It is involved in several key plant functions, including energy transfer, photosynthesis, transformation of sugars and starches, and nutrient movement within the plant. Ahn (1993) indicated that P is concentrated in the fast growing parts of the plant and, therefore, it hastens the maturing period of crops. Similar result was also reported by Ottman (2009) who reported that increase in $\mathrm{P}$ rate decreased time to heading, anthesis and maturity.

\subsubsection{Grain Filling Period}

Grain filling period, which is the number of days from heading to maturity, was significantly affected by $\mathrm{N}$ and $\mathrm{P}$, but not by their interaction (Table 3.). Nitrogen rates of 30 , 60,90 and $120 \mathrm{Kg} \mathrm{ha}^{-1}$ were similar with each other while they were significantly different from the control (Table 4.). Similar to days to maturity, $\mathrm{N}$ fertilization extended the number of days for grain filling. Nitrogen is very important in extending vegetative growth period (Chapman and Carter, 1976). 
Table 3. Mean squares of days to emergence, days to heading, days to maturity, grain filling period, plant height, number of total tillers and number of fertile tillers, as affected by main and interaction effects of $N$ and $P$.

\begin{tabular}{|c|c|c|c|c|c|c|c|c|c|}
\hline \multicolumn{10}{|l|}{ Mean Squares } \\
\hline $\begin{array}{l}\text { Source of } \\
\text { variation }\end{array}$ & df & $\begin{array}{l}\text { Days to } \\
\text { emergence }\end{array}$ & $\begin{array}{l}\text { Days to } \\
\text { heading }\end{array}$ & $\begin{array}{l}\text { Days to } \\
\text { maturity }\end{array}$ & $\begin{array}{l}\text { Grain filling } \\
\text { period }\end{array}$ & $\begin{array}{l}\text { Plant height } \\
\text { (m) }\end{array}$ & $\begin{array}{l}\text { Number of } \\
\text { total tillers }\end{array}$ & $\begin{array}{l}\text { Number of } \\
\text { fertile tillers }\end{array}$ & $\begin{array}{l}\text { Total biomass } \\
\left(\mathrm{t} \mathrm{ha}^{-1}\right)\end{array}$ \\
\hline Replication & 3 & 1.30 & 4.88 & $53.28 * *$ & $51.65 * * *$ & 0.01 & $1.88 *$ & 0.46 & 2.62 \\
\hline Nitrogen $(\mathrm{N})$ & 4 & 2.36 & $58.08 * * *$ & $169.00 * * *$ & $32.86 * * *$ & 0.01 & $0.36 \mathrm{~ns}$ & $1.81 * * *$ & $14.33^{* * *}$ \\
\hline Phosphorus(P) & 3 & 3.7 & $1448.01 * * *$ & $2675.75 * * *$ & $187.91 * * *$ & $0.08^{* * *}$ & $8.96 * * *$ & $9.57 * * *$ & $43.15^{* * *}$ \\
\hline$(\mathrm{N} * \mathrm{P})$ & 12 & 1.73 & $9.58 * * *$ & 15.94 & 4.84 & 0.003 & 0.37 & $0.31 * * *$ & 0.45 \\
\hline Error & 57 & 1.52 & 2.86 & 12.73 & 6.56 & 0.30 & 0.66 & 0.10 & 1.64 \\
\hline
\end{tabular}

ns-non significant. $* * *, * * *$ indicate significant difference at probability levels of $5 \%, 1 \%$ and $0.1 \%$ respectively.

Table 4. Mean values of days to emergence, days to heading, days to maturity, grain filling period, plant height, number of total tillers, and number of fertile tillers, as affected by $N$ and $P$

\begin{tabular}{|c|c|c|c|c|c|c|c|c|}
\hline & $\begin{array}{l}\text { Days } \\
\text { to emergence }\end{array}$ & $\begin{array}{l}\text { Days to } \\
\text { heading }\end{array}$ & $\begin{array}{l}\text { Days to } \\
\text { maturity }\end{array}$ & $\begin{array}{l}\text { Grain filling } \\
\text { period }\end{array}$ & $\begin{array}{l}\text { Plant height } \\
\text { (m) }\end{array}$ & $\begin{array}{l}\text { No. of total } \\
\text { tillers }\end{array}$ & $\begin{array}{l}\text { No. of fertile } \\
\text { tillers }\end{array}$ & $\begin{array}{l}\text { Total biomass } \\
\left(\mathrm{t} \mathrm{ha}^{-1}\right)\end{array}$ \\
\hline \multicolumn{9}{|l|}{$\mathrm{N} \mathrm{Kg} \mathrm{ha}^{-1}$} \\
\hline 0 & 8.9 & $77.1^{\mathrm{b}}$ & $120.9^{c}$ & $43.8^{\mathrm{b}}$ & 1.06 & 3.8 & $2.5^{\mathrm{c}}$ & $6.51^{\mathrm{c}}$ \\
\hline 30 & 9.3 & $78.1^{\mathrm{b}}$ & $123.8^{\mathrm{b}}$ & $45.7 \mathrm{a}$ & 1.06 & 4.0 & $2.9^{\mathrm{b}}$ & $6.64^{\mathrm{c}}$ \\
\hline 60 & 9.5 & $80.5^{\mathrm{a}}$ & $127.9^{\mathrm{a}}$ & $47.4^{\mathrm{a}}$ & 1.06 & 4.0 & $3.2^{\mathrm{a}}$ & $7.59^{\mathrm{b}}$ \\
\hline 90 & 9.7 & $80.6^{\mathrm{a}}$ & $127.4^{\mathrm{a}}$ & $46.8^{\mathrm{a}}$ & 1.10 & 4.1 & $3.3^{\mathrm{a}}$ & $7.96^{\mathrm{ab}}$ \\
\hline 120 & 9.9 & $81.7^{\mathrm{a}}$ & $128.6^{\mathrm{a}}$ & $46.9^{\mathrm{a}}$ & 1.11 & 4.1 & $3.2^{\mathrm{a}}$ & $8.78^{\mathrm{a}}$ \\
\hline LSD $5 \%$ & NS & 1.2 & 2.5 & 1.8 & NS & NS & 0.2 & 0.91 \\
\hline \multicolumn{9}{|l|}{$\mathrm{P} \mathrm{Kg}^{-1}$} \\
\hline 0 & 10.0 & $92.0^{\mathrm{a}}$ & $142.7^{\mathrm{a}}$ & $50.7^{\mathrm{a}}$ & $0.99^{c}$ & $3.0^{\mathrm{c}}$ & $2.1 \mathrm{c}$ & $5.57^{\mathrm{c}}$ \\
\hline 23 & 10.0 & $78.2^{\mathrm{b}}$ & $123.5^{\mathrm{b}}$ & $45.3^{b}$ & $1.08^{\mathrm{b}}$ & $3.9^{\mathrm{b}}$ & $2.9 \mathrm{~b}$ & $7.17^{\mathrm{b}}$ \\
\hline 46 & 9.0 & $75.0^{\mathrm{c}}$ & $119.5^{\mathrm{c}}$ & $44.5^{\mathrm{b}}$ & $1.11^{\mathrm{ab}}$ & $4.5^{\mathrm{a}}$ & $3.5 \mathrm{a}$ & $8.33^{\mathrm{a}}$ \\
\hline 69 & 9.0 & $73.3^{d}$ & $117.3^{\mathrm{c}}$ & $44.1^{\mathrm{b}}$ & $1.13^{\mathrm{a}}$ & $4.4^{\mathrm{a}}$ & $3.6 \mathrm{a}$ & $8.91^{\mathrm{a}}$ \\
\hline LSD $5 \%$ & NS & 1.1 & 2.3 & 1.6 & 0.04 & 0.5 & 0.2 & 0.81 \\
\hline $\mathrm{CV}$ & 13.04 & 2.1 & 2.8 & 5.6 & 6.7 & 20.6 & 10.4 & 17.08 \\
\hline
\end{tabular}

Means in the column with the same letter are not significantly different. NS- Non significant

In contrast, the treatments which received $\mathrm{P}$ have taken significantly lower number of days than the control for grain filling (Table 4). 44 days were taken for grain filling period in the treatment which received $69 \mathrm{Kg} \mathrm{P} \mathrm{ha}^{-1}$, against 51 days in the control treatment, which was a week's difference. But there was no significant difference among 23, 46 and $69 \mathrm{Kg}$ $\mathrm{P} \mathrm{ha}{ }^{-1}$ treatments. Days to heading, days to maturity, and grain-filling period showed similar trends in their response to $\mathrm{P}$ application, in that $\mathrm{P}$ fertilization shortened developmental period of the various phases.

\subsection{Growth and Related Parameters}

\subsubsection{Plant Height}

Plant height was not significantly affected by different $\mathrm{N}$ rates, whereas $\mathrm{P}$ application significantly increased plant height (Table 3.). The absence of $\mathrm{N}$ effect on height of barley might be attributed to residual $\mathrm{N}$ accumulation in the soil. The soil analysis showed a medium total $\mathrm{N}$ accumulation (Table 1.). Nitrogen contained in the residues from previous crops is an important source of N. Manure is also good source of organic matter and N. Farmers in Bore area usually release their cattle to the farm land after harvest. On the other hand, Rashid et al, (2007) indicated that plant height was linearly increased with increasing levels of $\mathrm{N}$ fertilization. The difference between the two results might be due to difference in soil and agro-climatic conditions. The experiment by Rashid et al. (2007) was conducted in arid zone which received $182 \mathrm{~mm}$ rain fall during the growing period. Most of the time, arid zone soils are salt affected soils in which nutrient availability is influenced.

Application of P slightly increased plant height (Table 4.). The longest plant height of $1.13 \mathrm{~m}$ was recorded at the highest $\mathrm{P}$ rate of $69 \mathrm{Kg} \mathrm{ha}^{-1}$ and it was at par with $\mathrm{P}$ rate of 46 $\mathrm{Kg} \mathrm{ha}^{-1}$. The shortest plant height of $1 \mathrm{~m}$ was recorded in $\mathrm{P}$ rate of $0 \mathrm{Kg} \mathrm{ha}^{-1}$. Mengel and Kirkby (1987) reported that phosphorus deficiency in small grains is usually expressed as stunted growth.

\subsubsection{Lodging}

The crop was affected by lodging (Table 5.). From the lodging indices calculated, the lodging was much attributed to $\mathrm{N}$ and $\mathrm{P}$, and other physical factors can also hasten it. Together with prevailed windy and excessive rain fall condition at the experimental site during grain filling period, plants of relatively weaker stems and those which were very tall in height might have been exposed to lodging. Highest lodging index was recorded in the plots which received the combination of maximum $\mathrm{N}$ and $\mathrm{P}$ rates. Literatures indicate that when crops receive large amount of $\mathrm{N}$ their physical strength decreases (Anonymous, 1996).

As it was indicated in plant height, $\mathrm{P}$ significantly increased plant height. The increase in plant height might expose it to lodging. For example, lodging indexes of 3.8, 1.7, 1.5 and 1 were calculated in the treatments 120-69, 120-46, 120-23 and 90-69 Kg ha ${ }^{-1} \mathrm{NP}$ combinations respectively (Table 5.). 
On the other hand, moisture saturated soil at the experimental site might be another reason for highly grown plants to lodge, because it might affect strength of root anchorage.

Table 5. Lodging index records at different NP combinations of barley at Bore.

\begin{tabular}{|c|c|c|c|c|}
\hline & P K & & & \\
\hline $\mathrm{N} \mathrm{Kg} \mathrm{ha}^{-1}$ & 0 & 23 & 46 & 69 \\
\hline 0 & 0.0 & 0.0 & 0.1 & 0.1 \\
\hline 30 & 0.0 & 0.0 & 0.0 & 0.2 \\
\hline 60 & 0.0 & 0.0 & 0.0 & 0.3 \\
\hline 90 & 0.0 & 0.2 & 0.5 & 1.0 \\
\hline 120 & 0.1 & 1.5 & 1.7 & 3.8 \\
\hline
\end{tabular}

\subsubsection{Tillering}

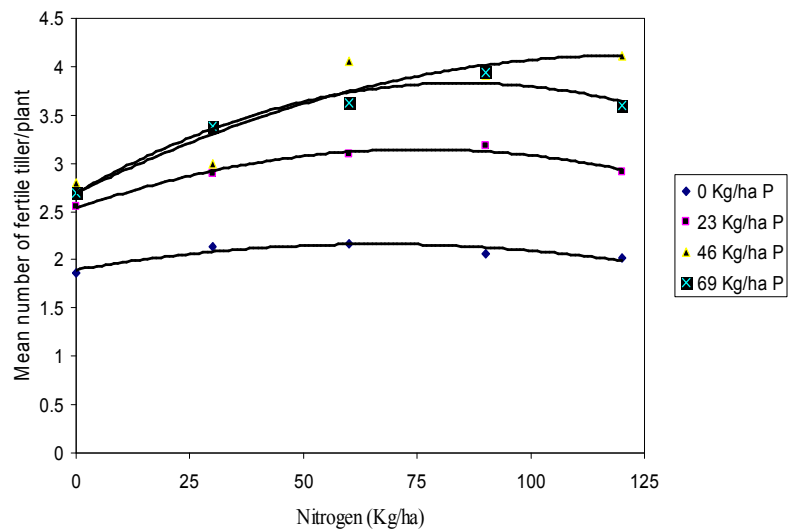

Fig 1. Interaction effect of Nitrogen and Phosphorus on number of fertile tillers of barley at Bore.

Number of total tillers/plant significantly responded to $\mathrm{P}$, but was not significantly affected by $\mathrm{N}$ and NP interaction (Table 3). Highest number of tillers was recorded at $\mathrm{P}$ level of $46 \mathrm{Kg} \mathrm{ha}^{-1}$ which was not statistically different from $\mathrm{P}$ level of $69 \mathrm{Kg} \mathrm{ha}^{-1}$ (Table 4). Number of total tillers at P rates of 46 and $69 \mathrm{Kg} \mathrm{ha}^{-1}$ were significantly superior to number of tillers at 23 and $0 \mathrm{Kg} \mathrm{ha}^{-1}$ (Table 4). According to this experiment, $\mathrm{N}$ did not significantly affect number of total tillers, but it significantly affected the number of fertile (effective) tillers. Both $\mathrm{N}$ and $\mathrm{P}$ significantly increased number of effective tillers/plant. The interaction between fertilizer levels was also significant (Fig 3). It was observed that the upper two $\mathrm{P}$ rates (46 and $69 \mathrm{Kg} \mathrm{ha}^{-1}$ ) did not differ in number of fertile tillers over most of the $\mathrm{N}$ rates, except at the two highest $\mathrm{N}$ rates (Fig. 1). Application of $46 \mathrm{Kg} \mathrm{P} \mathrm{ha}^{-1}$ with the highest $\mathrm{N}$ rate seemed the most favorable for number of fertile tillers. Maqsood et al (1999) reported that the increase in the number of fertile tillers with increasing nitrogen levels could be attributed to the well-accepted role of nitrogen in accelerating vegetative growth of plants. But, according to this experiment, the contribution of $\mathrm{P}$ was also very high, because number of tillers is significantly low in those treatments which did not receive P. It agrees with the result obtained by Prystupa et al (2004), who reported that number of productive tillers/plant was affected significantly by NP fertilizer application. They indicated that maximum number of productive tillers were recorded in 69-69 N/P kg $\mathrm{ha}^{-1}$ fertilizer rates, and lowest number of the productive tillers was given by $0-0 \mathrm{Kg} \mathrm{ha}^{-1} \mathrm{~N} / \mathrm{P}$ treatment. Similar results were also reported by Anderson et al. (2002) from their research on barley.

\subsubsection{Total Biomass}

Both $\mathrm{N}$ and $\mathrm{P}$ significantly influenced total biomass but their interaction effect was not significant (Table 3 ). The highest TBM of $8.78 \mathrm{t} \mathrm{ha}^{-1}$ was recorded in the treatment which received $120 \mathrm{~kg} \mathrm{~N}^{-1}$ though not significantly different to the TBM obtained from $90 \mathrm{Kg} \mathrm{N} \mathrm{ha}^{-1}\left(7.96 \mathrm{t} \mathrm{ha}^{-1}\right)$ (Table 4). The lowest TBM of $6.51 \mathrm{t} \mathrm{ha}^{-1}$ was recorded in the treatment that received no $\mathrm{N}$. The 90 and $120 \mathrm{Kg} \mathrm{N}^{-1}$ produced higher TBM of $22.3 \%$ and $35.0 \%$ over the control, respectively. Nitrogen increases vegetative growth of plants, especially at higher doses. Besides, the significant increase in spike length, number of seeds per spike, number of fertile tillers and grain yield by $\mathrm{N}$ contributed for the significant increase in TBM. This is in agreement with Alam and Haider (2006) who indicated that increased nitrogen level increased total dry matter irrespective of cultivars.

The highest TBM of $8.91 \mathrm{Kg}$ ha-1 was obtained from the highest $\mathrm{P}$ level (69 Kg ha-1) though not significantly different from $8.33 \mathrm{Kg}$ ha-1 obtained at $46 \mathrm{Kg}$ ha-1 P (Table 4). Significant increases in plant height, tillering, spike length, number of spikelets per spike and grain yield from $P$ application contributed to the increased TBM from $\mathrm{P}$ application. Total biomass was positively and significantly correlated with plant height $(\mathrm{r}=0.64 * * *)$, tillering $\left(\mathrm{r}=0.55^{* * *}\right)$, spike length $\left(\mathrm{r}=0.44^{* * *}\right)$, number of spikelets per spike $\left(\mathrm{r}=0.51^{* * *}\right)$, straw yield $(\mathrm{r}=0.93 * * *)$ and 1000 grain weight $(\mathrm{r}=0.23 *)$. Other authors also reported similar results from researches conducted on wheat (Alcoz et al. 1993, Tilahun Geleto et al. 1996) indicating that $P$ significantly increased TBM.

\section{Summary and Conclusion}

Nutrient requirement of plants can be varied from location to location depending on different factors such as soil and other agro-ecologies. For sustainable production of crops for a particular area, specific fertilizer recommendation is very crucial. For this reason a field experiment was conducted in Bore Woreda, Ethiopia in 2009. Bore is found at Southeast of the capital, Addis Ababa, at around $380 \mathrm{~km}$. The area has an altitude of $2712 \mathrm{~m}$ a.s.1 with annual rain fall of $1496 \mathrm{~mm}$. The soil is clay loam with $\mathrm{pH}$ of 6 (slightly acidic). Even though large numbers of households depend on crop production, farmers are not using new technologies including new varieties and appropriate package of fertilizers. Barley is the most important staple food crop in the area. This experiment was conducted to assess the effect of $\mathrm{N}$ and $\mathrm{P}$ on yield and yield components of barley. The experiment contained five levels of $\mathrm{N}\left(0,30,60,90\right.$ and $\left.120 \mathrm{Kg} \mathrm{ha}^{-1}\right)$ and four levels of P $\left(0,23,46,69 \mathrm{Kg} \mathrm{ha}^{-1}\right)$, where, UREA (46-0-0) was used as a source of $\mathrm{N}$ and TSP (0-46-0) was used as 
source of P. A total of twenty treatment combinations were tested. The treatments were arranged in factorial randomized complete block design (RCBD) with four replications.

The barley variety used as test crop in this experiment was known as Biftu. This variety is the newly released variety.

Many of the growth and development parameters observed responded to $\mathrm{N}$ fertilization. Days to heading, days to maturity, grain filling period, number of fertile tillers and total biomass were significantly influenced by $\mathrm{N}$ application, whereas days to emergence and plant height were not significantly affected by N. Nitrogen application delayed days to heading, days to maturity and extended the grain filling period. Number of fertile tillers and TBM and were significantly increased by $\mathrm{N}$ fertilization. The increases in these parameters directly or indirectly contributed to the increase in grain yield.

In this experiment, the effect of $\mathrm{P}$ was more pronounced than that of N. Except days to emergence; all the parameters observed were significantly affected by $\mathrm{P}$ application. This includes days to heading, days to maturity, grain filling period, number of total tillers, number of fertile tillers, and total biomass. Contrary to $\mathrm{N}$, it significantly decreased number of days to heading, maturity, and grain filling period. Other parameters, such as, plant height, number of fertile tillers, and TBM, were significantly increased by $\mathrm{P}$ rates. Therefore, $\mathrm{N}$ and $\mathrm{P}$ fertilizers are very important nutrients in limiting the growth and development of crops which has direct effect on productivity of the crops.

\section{Acknowledgements}

I express my deepest and heart-felt gratitude to Oromia Agricultural Research Institute (OARI) for granting fund for this research. I want to extend my appreciation and special thanks to Crop Research Division researchers of YPDARC Desalegn Regassa and Tolessa Taye for they were helping me from the very beginning of the research, land preparation to data collection.

Furthermore, I would greatly acknowledge Hawassa Agricultural research center for letting me to use laboratory and laboratory materials during soil and plant analysis.

\section{References}

[1] Ahn PM (1993). Tropical soils and fertilizer use. Long man group, UK.

[2] Alam MZ, SA Haider (2006). Growth attributes of barley (Hordeum vulgare L.) cultivars in relation to different doses of nitrogen fertilizer. Journal of Life Earth Science. 1: 77-82.

[3] Alcoz M, M Frank, V Haby (1993). Nitrogen fertilizer timing effect on wheat production, nitrogen uptake efficiency, and residual soil nitrogen. Agronomy Journal, 85: 1198-1203.

[4] Anderson PM, EA Oelke, SR Simmons (2002). Growth and Development Guide for Spring Barley. University of Minnesota, USA.
[5] Anonymous (1996). Small grain production. Ohio Agronomy guide, Bulletin 472 Ohio State University, USA.

[6] Caldicott JJ AM Nuttall (1979). A method for the assessment of lodging in cereal crops. Journal of National and International Agriculture and Botany, 15: 88-91.

[7] Chapman RC, LP Carter (1976). Crop production: principles and practices. Freeman Company, USA.

[8] CLDB (Canada land development branch). 2001. Crop fertilization guide. New Nouveau Brunswick, Canada.

[9] Damene Darota (2003). Yield Response of Bread Wheat (Triticum aestivum L.) to applied Levels of $\mathrm{N}$ and P Fertilizers on Nitisol of Dawro Zone, Southwestern Ethiopia, M.Sc. thesis. Haramaya University, Haramaya.

[10] Desta Beyene (1987). Effect of liming and N and P fertilizers on grain yield of barley. Ethiopian Journal of Agricultural Sciences (1): 1-13.

[11] Edney MJ, KH Tipples (1997). Crop bulletin. ISSN 11824417, No 235. Grain Research Laboratory, Canadian grain comission, Canada.

[12] Grando S, HG Macpherson (eds.) (2005). Food Barley: Importance, Uses and Local Knowledge. Proceedings of the International Workshop on Food Barley Improvement, 14-17 January 2002, Hammamet, Tunisia. ICARDA, Aleppo, Syria, $\mathrm{x}+156$ pp. En.

[13] Hailu G, Van Luer Joop (1996). Barley research in Ethiopia: Past work and future prospects. Proceedings of the first Barley Research Review workshop, 16-19 October 1993, Addis Ababa.

[14] Havlin JL, JD Beaton, SL Tisdale, WL Nelson (1999). Soil fertility and fertilizers: An introduction to nutrient management. Prentice Hall, New York, 499p.

[15] IAR (Institute of Agricultural Research) (1979). Cooperative program for Chencha. IAR/ADD progress report for 19751976. Addis Ababa, Ethiopia.

[16] ICARDA (International Center for Agricultural Research in Dry Areas) (2008). Barley improvement production, Allepo, Syria

[17] Maqsood M, M Akbar, N Yousaf, MT Mehmood, S Ahmad (1999). Effect of different rates of N, P and K combinations on Yield and components of Yield of wheat. International Journal of Agriculture and Biology 1 (4): 359-361.

[18] Mengel K, EA Kirkby (1987). Principles of Plant Nutrition. $\left(4^{\text {th }}\right.$ Ed.). International potash institute, Bern, Switzerland.

[19] Olsen SR, CV Cole, FS Watanabe, LA Dean (1954). Estimation of available phosphorus in soils by extraction with sodium bicarbonate. USA Circular. 939: 1- 19.

[20] Ottman MJ (2009). Response of wheat and barley varieties to phosphorus fertilizer. University of Arizona, USA.

[21] Prystupa P, G Slafer, A Savin (2004). Leaf appearance, tillering and their coordination in response to NxP fertilization in barley. Springer, Netherlands.

[22] Rashid A, Khan UK, Khan DJ (2007). Comparative Effect of Varieties and Fertilizer Levels on Barley (Hordeum vulgare). ISSN Online: 1814-9596, Pakistan. 
[23] SAS Institute (2004). SAS User's Guide, Statistics version 9 ed. SAS Institute, Cary, NC, USA.

[24] Shrivastava BK, MP Singh, SK Jain (1992). Effect of spacing and nitrogen levels on growth, yield and quality of seed crops of radish. Seed Res., 20: 85-7.

[25] Taye Bekele, Yeshanew Ashagrie, Balesh Tulema, Girma Gebrekidan (1996). Soil fertility management in barely. In: Hailu and Joop van Leur (eds). Barely research in Ethiopia: past work and future prospects. Proceedings of the first barely research review workshop, 16-19 October 1993, Addis Ababa: IAR/ICARDA, Addis Ababa, Ethiopia. pp. 92-99

[26] Tilahun Geleto, Tanner DG, Tekalign Mamo, Getinet
Gebeyehu (1996). Response of rain fed bread and durum wheat to source, level and timing of nitrogen fertilizer at two Vertisol sites in Ethiopia. pp. 127-147. In: The Ninth Regional Wheat Workshop for Eastern, Central and Southern Africa. Addis Ababa, Ethiopia.

[27] Westerman RL (1990). Soil Testing and Plant Analysis. (3 ED). Soil Science Society of America, Inc. Madison, Wisconsin, USA.

[28] Woinshet Tariku (2007). Effect of nitrogen fertilizer levels on grain yield and malt quality of different malt barley (Hordeum vulgare L.) varieties in Shashemane woreda. MSc. thesis, Hawassa University, Hawassa, Ethiopia. 